\title{
通風開口部の流入気流と圧力損失に関する実験的研究 \\ EXPERIMENTAL STUDY ON PENETRATING FLOW AND PRESSURE LOSS THROUGH OPENINGS IN A CROSS-VENTILATED MODEL BUILDING
}

\author{
大場 正昭*, 倉㴊 隆**, 入江謙治*** \\ Masaaki OHBA, Takashi KURABUCHI and Kenji IRIE
}

\begin{abstract}
Cross-ventilation is a valuable tool in achieving comfortable indoor temperatures in humid areas with high summer temperatures. However, the simplified design procedure for utilizing cross-ventilation is not established yet, because the interaction of the internal flow with the envelope flow greatly complicates the flow characteristics inside a room. The wind tunnel is the best way to account for wind effects and measure directly ventilation flow rates. In this study, split-film probes measured the directional velocities and turbulence levels inside and outside a cross-ventilated model. The penetrating flow entered the inlet opening at steep declining angles due to the front eddy and the downwash flow along the upwind face. The penetrating flow flowed downwards the floor. Internal turbulence spectrum of the main stream remained the same as that of the oncoming flow, but the spectra of other components were produced by the inlet and internal turbulence. The ventilation flow rates decreased until $45^{\circ} \leqq \theta$. The Pitot tube was set for the incidence angles of the penetrating flow obtained by the split-film probes at the upwind opening. The pressure loss coefficients for the inlet opening were calculated from the pressure difference between the total pressure and internal pressure. It was found that the pressure loss coefficients greatly depended on wind directions and incidence angles of the penetrating flow.
\end{abstract}

Keywords: Cross-ventilation, Opening, Penetrating flow, Wind direction, Pressure loss coefficient, Wind tunnel experiment 通風、開口部、流入気流、風向角、圧力損失係数、風洞実験

1. 序

自然通風は夏季に蒸暑気候となる地域で、冷涼感を得たり、大量 の発生熱や污染物を除去したりするのに有効である 1。また、自然 換気と空調を組み合わせたハイブリット型空調システムは、自然換 気利用による冷房負荷の削减効果の視点で積極的に導入されている 2)。しかし、効率的に通風を得る方法や良い通風環境を形成する手 法は、通風気流が建物内外の気流が相互に影響を及ぼす複雑乱流と なることから、現状ではその解明が充分に進んでおらず、その手法 が明確には示されていない。

従来の通風量は、一般に開口のない建物模型を用いて風洞実験に よって測定された風圧係数と、チャンバー法によって測定された開 口の流量係数から算出される。チャンバー法は、無風時の「静止空間 から静止空間への開口部」にういて、チャンバー内外の圧力差と流量 の関係から開口部の圧力損失係数を求めるものである 3 。有風時の 圧力損失は無風時の圧力損失とは異なるので、実際の通風量よりも 過大に評価することが報告されている4)。これに対して石原は、通
風においては一般に、開口間の距離が開口寸法に対し、比較的短い ので、各開口の抵抗の相互干涉が生じるとして、従来の計算法を補 正するための干涉係数を導入した ${ }^{3)}$ 。山中らは干渉係数の整備を目 指している 5。加藤はエネルギー保存に基づくパワーバランスモデ ルを提案し、通風室内の流管が明確な場合に有効であることを検討 した ${ }^{6}$ 。しかし、流れのエネルギーが空内で消失する場合にはモデ ルの適用が難しい。

筆者らは、自然通風・換気を室内環境調整 7に有効利用するため には、まず通風時における建物内外の乱流現象を実験的に把握する ことが不可欠であると考え、そのための手段として風洞実験 8)を活 用してきた。

近年、実験を代替する検討手法として数值シミュレーションが注 目され、 $\mathrm{k}-\varepsilon$ モデル用いた計算が実用予測法として広く実施さ れている 9.10)。風洞実験では精密な計測が困難な空間の静圧分布 11 の収集が可能になる。しかし、建物前面の衝突域での乱れの過大生 産、端部での剥離流形成、屋根面の再付着流、開口部の伸縮歪の評価

\footnotetext{
* 東京工芸大学 教授.工博

** 東京理科大学 助教授・工博

*** 䀛ビス・アティック
}

Prof., Tokyo Institute of Polytechnics, Dr. Eng. Assoc. Prof., Science Univ. of Tokyo, Dr. Eng. Bis At'tic Inc. 
等に問題点が多い 12.13)。そこで数值シミュレーションの妥当性を明 らかにする必要があるが、数值モデルの検証に供し得る通風時の複 雑乱流を詳細に測定した実験データが充分整備されていない 14)。

本研究では、以上の述べた背景から、単純建物周辺気流を対象に、 通風時における開口部の流入気流と圧力損失の関係について風洞実

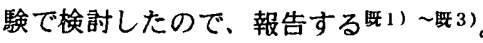

\section{2. 实験概要}

\section{1 風洞}

エッフェル型吹き出し式風洞で、測定部は長さ $14 \mathrm{~m}$ 、幅 $1.2 \mathrm{~m}$ 、 高さ $1 \mathrm{~m}$ である。

\section{2 建物簒型}

図ー1に開口部なし模型と通風模型を示す。長さ $300 \mathrm{~mm}$ 、幅 $300 \mathrm{~mm}$ 、高さ $150 \mathrm{~mm}$ で開口部を有しない建物模型 Case 1 と、同 形状で幅 $60 \mathrm{~mm}$ 、高さ $30 \mathrm{~mm}$ の開口部を 2 個有する通風模型 Case 2 〜Case 4 を用いた。通風模型は屋外気流、室内気流及び開口部流入 気流の測定項目ごとに模型タイプを選択した。模型板厚は $8 \mathrm{~mm}$ 。

室内気流用の模型は、屋根面に直径 $18 \mathrm{~mm}$ の測定孔を 77 简所設 け、さらに室内の鈶直面風速ベクトル測定のために、側壁に直径 $15 \mathrm{~mm}$ の測定孔を有するスライド式の板を 7 籄所に取り付けた。開 口部流入気流用の模型は、開口部上部の壁面に角欠きを入れて風速 プローブをはめ込めるようにした。

壁面風圧模型は Case 1 と Case 2 の模型表面に内径 $1 \mathrm{~mm} \mathrm{~m}^{\Phi}$ 、外形 1.7mm の真鍮パイプを埋め込んだ。Case 1 の測定点は 300 点、通風 模型 Case 2 は 143 点で、開口部近傍に測定点を密に配置した。

\section{3 胡測器}

室内外風速とスペクトル測定に気流の方向成分を測定できるスプ リットフィルムプローブ（TSI 社の 1288 型）と熱線風速計 （KANOMAX）2 台を使用した。風圧測定には微差圧計（MKS バ ラトロン、娜定精度 $0.1 \mathrm{~Pa}$ ）を、カス数度測定には炭化水素分析計 （大倉理化学研究所、測定精度 $1 \times 10^{-7} \mathrm{~m}^{3 /} / \mathrm{m}^{3}$ ) を使用した。

\section{4 実䀦婪件}

図-2 2 接近流の銠直風速分布、乱流エネルギー分布、及び風速 変動のスペクトル分布を示す。市街地風を想定し、パリヤー、ボル テックス発生装置 15)、粗度ブロックを組み合わせて、鉛直風速分布 が $1 / 4$ 乗則に従う乱流境界首を作成した。基準風速は $\mathrm{Z} / \mathrm{H}=1.0$ で 平板上の風速 $\mathrm{U}_{0}$ を $7.0 \mathrm{~m} / \mathrm{s}$ に設定した。風速変動のスペクトルは、 図の横軸を無次元周波数で表示し、周波数を測定高さ $\mathrm{Z}=150 \mathrm{~mm}$ と その高さでの風洞気流で基準化した。スペクトルは主流方向がスパ ン方向に比べて低周波側に存在する形を示した。表一 1 に実賖条件 を示す。室内外気流、風圧係数、風速変動スペクトル、通風量、開 口部流入風速、及び開口部全圧の 6 タイプを測定した。

図ー3にピトー全圧管の仕様を示す。円筒管先端部を直角に切断 した断面形状に製作した。図ー4に指向特性を示す。真の風向に対 して $\pm 20^{\circ}$ の䉇囲で設置すれば、充分な精度で全圧の測定が可能で ある。

\section{5 測定方济}

(1) 室内外気流

鈶直面の風速ベクトルは、模型中心軸 $\mathrm{Y} / \mathrm{H}=0$ 上でプロープの角度 を回転させて気流の 3 成分を測定した。図一 5 に通風模型の鉛直面
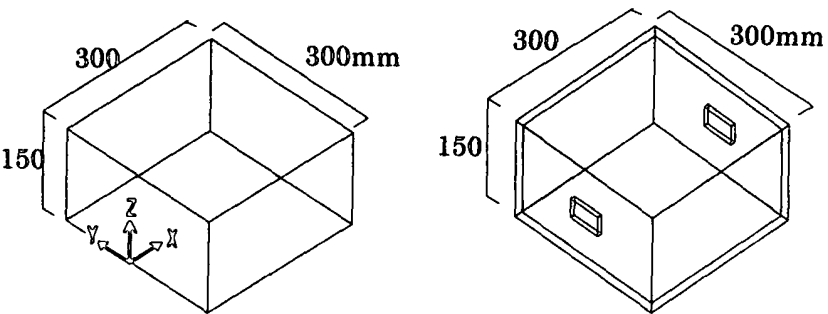

（1）開口部なし模型（Case 1）

(2)屋外気流の通風模型(Case2) 開口部
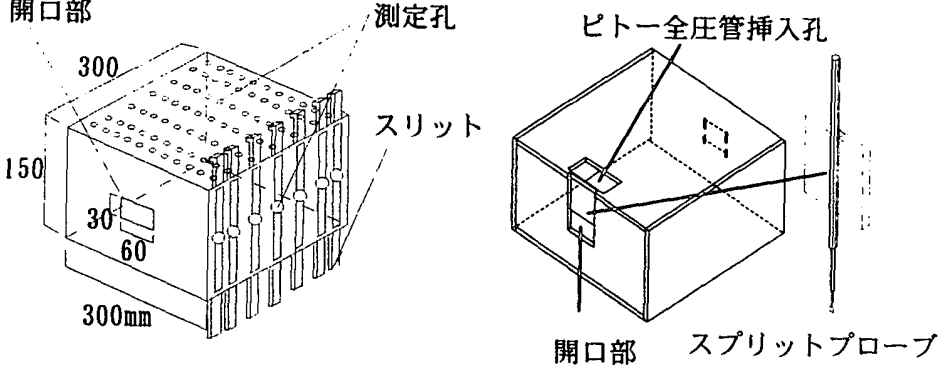

（3)室内気流の通風模型(Case3）（4)開口部気流の通風模型(Case4) 図一1 開口部なし模型と通風模型

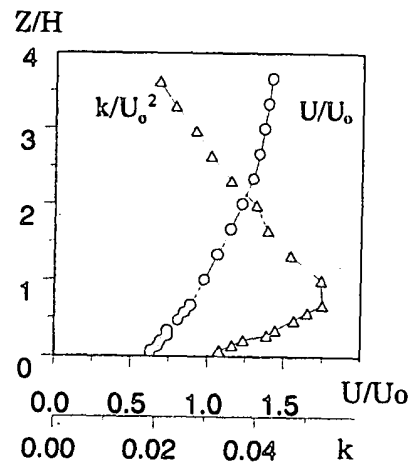

（1）平均風速と乱流エネルギー

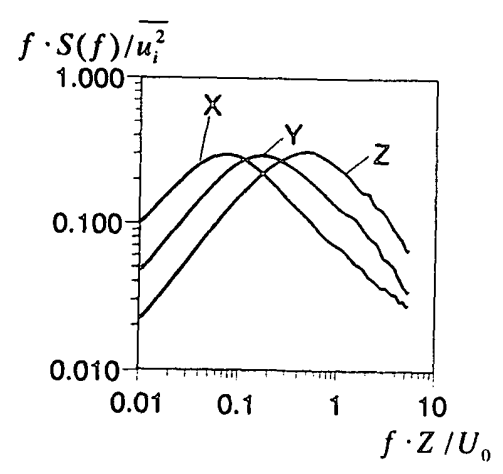

(2)軒高のスペクトル分布

図-2 接近流の気流性状

表 -1 実験条件

\begin{tabular}{|c|c|c|c|c|c|}
\hline No & 㨨定项目 & 的測㗼 & 楛型 & $U_{Q}$ & 風向角 \\
\hline \multirow{2}{*}{1} & \multirow{2}{*}{ 经内外毁流 } & \multirow{2}{*}{ スプリット } & Case1 & \multirow{7}{*}{$7 \mathrm{~m} / \mathrm{s}$} & $0^{\circ}$ \\
\hline & & & Case2,3 & & $0^{\circ}, 45^{\circ}$ \\
\hline 2 & 图区係部 & 触遧压的 & Case 1 & & $0^{\circ} .45^{\circ}$ \\
\hline 3 & 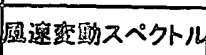 & スプリット & Case 1 & & $0^{\circ}$ \\
\hline 4 & 通風䡃 & 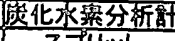 & $\frac{\text { Cases }}{\text { Case2 }}$ & & \multirow{3}{*}{$0^{\circ} \sim 75^{\circ}$} \\
\hline 5 & 關口部流入風速 & 줍ッ & \multirow{2}{*}{ Case 4} & & \\
\hline 6 & 開口部全压 & 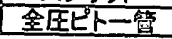 & & & \\
\hline
\end{tabular}

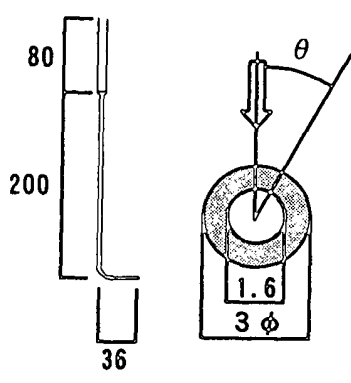

図-3 ピトー全圧管

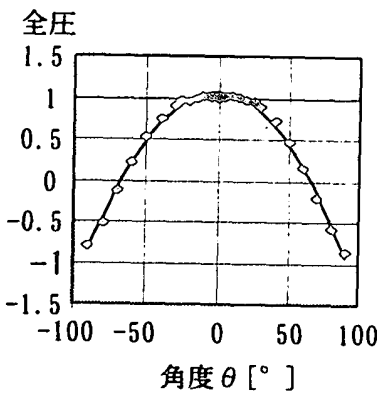

図-4 ピトー全圧管の 指向特性 
測定点を示す。建物近傍に測定点を密に配置し、323 点選定した。 通風模型の屋外気流は Case 2 を、室内気流は Case 3 の模型を用い た。Case 3 の測定では、側面中央の直径 $15 \mathrm{~mm}$ の孔からスプリッ トプローブを挿入し、スリットをスライドさせながらスプリットプ ローブを移動して X，Z の風速成分を測定した。アプローチフロー が開口部に正対する風向角 $0^{\circ}$ のときにスリットを上下させた。測 定以外のときはスリットを下げて、周辺気流への影響を極力小さく なるように配慮した。Y 成分の風速は天井面からスプリットプロー ブを挿入して測定した。サンプリング周波数 $250 \mathrm{~Hz}$ 、ローパスフィ ルター $125 \mathrm{~Hz}$ 、平均化時間 60 秒である。水平面の風速べクトルは $\mathrm{Z} / \mathrm{H}=0.5$ で $\mathrm{X} 、 \mathrm{Y}$ 成分の 2 成分を測定した。

\section{（2）風圧係数}

各風圧孔から内径 $1.4 \mathrm{~mm} \Phi$ のビニールチューブでスキャニーバル ブまで接続して微差压計で壁面風圧を測定した。風洞内静圧は平板 上の模型高さでの $\mathrm{X} / \mathrm{H}=0, \mathrm{Z} / \mathrm{H}=1$ の静圧を基準とした。平均風圧係 数は壁面風圧を基準風速 $7 \mathrm{~m} / \mathrm{s}$ の動圧で基準化して算出した。ビニ 一ルチューブの長さは約 $100 \mathrm{~cm}$ で、平均化時間は 60 秒とした。

\section{（3）風速変動スペクトル}

サンプリング周波数は $500 \mathrm{~Hz}$ 、ローパスフィルター $250 \mathrm{~Hz}$ で 2048 点の時系列のデータを 16 回採取し、AR 法で解析した。スぺ クトル分布は 16 回のスペクトルを集合平均したものである。

\section{（4）通風量}

通風模型 Case 2 の屋根面から外形 $6 \mathrm{~mm}$ 、内径 $4 \mathrm{~mm}$ のパイプを 挿入し、模型内でエチレンガスを $10 \mathrm{cc} / \mathrm{s}$ 連続放出させ、流出開口

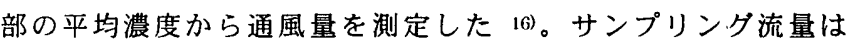
$1.7 \mathrm{cc} / \mathrm{s}$ である。測定点は流出開口部を均等分割した 6 点とした。 計測器は炭化水素分析計を用いた。平均化時間は 60 秒である。

\section{（5）開口部流入風速}

図ー 1 (4)に示すように、流入開口部上部の角欠きにスプりットフ イルムプローブを沿わせて、開口部の中心高さで X 成分と $\mathrm{Y}$ 成分 の流入風速を測定した。測定時間は 60 秒である。

（6）開口部全圧と室内静圧

開口部全圧の測定点は開口部の中心高さで、スプリット風速計で 得られた水平面の流入風向角にピト一全圧管の向きを合わせて、開 口部前縁で測定した。この点の全圧を開口部全圧とした。測定時間 は 60 秒である。室内静圧は室内で下降する流入気流の影響を避け るために天井面で測定した。測定点は天井面を均等分割した 4 点と 中央点の合わせた 5 点として、 5 点の平均値を室内静圧值とした。

\section{3. 実験結果及び考察}

\section{1 建物内外の気流性状}

\section{(1). 通気輪道}

図ー6に開口部なし建物模型周りの鈶直断面流れを対比のために 示す。アプローチフローは風上側壁面の $\mathrm{Z} / \mathrm{H}=2 / 3$. 付近で上下に分岐 し、下降する流れは床面近くで逆流して循環瀜を形成した。上昇す る流れは風上側屋根面端部で剥離し、直ちに下降して屋根面に沿つ て流れた。風速測定を屋根面から $\mathrm{Z} / \mathrm{H} \geqq 1 / 15$ の領域に限定したので、 屋根面の渦を捉えることができなかった。

図ー7に通風模型の鈶直面風速べクトル分布を示す。流れは風上 屋根面端部で剥離する気流、模型内に流入する気流、模型上流面下
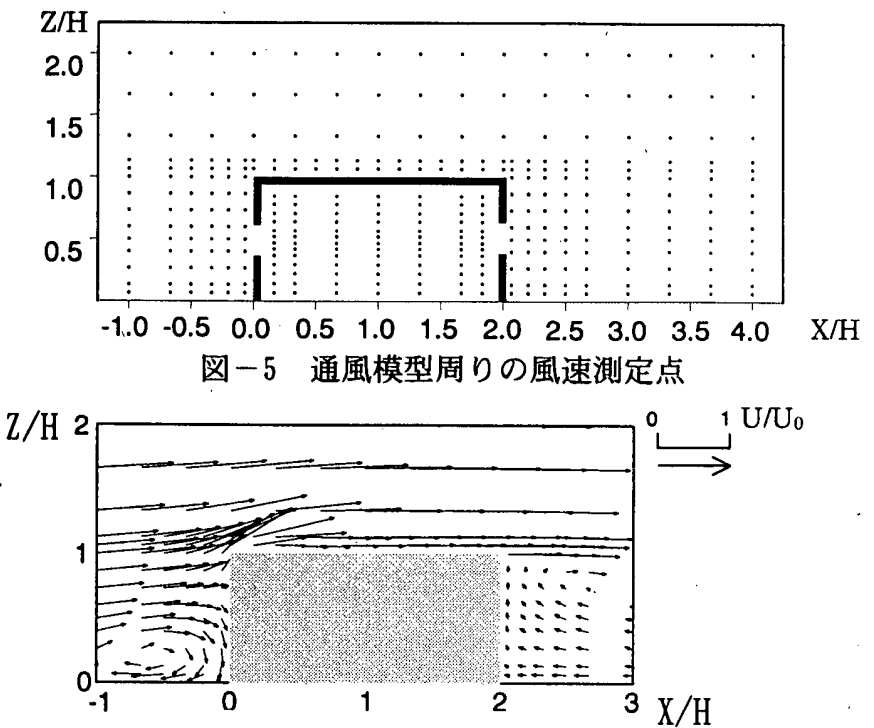

図－6 開口部なし模型周りの鈶直風速ベクトル分布 $\left(\theta=0^{\circ}\right)$

$\mathrm{Z} / \mathrm{H}$

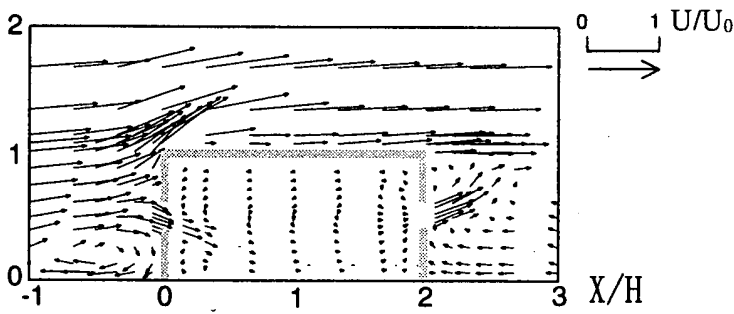

図-7 通風模型周りの銷直風速ベタトル分布 $\left(\theta=0^{\circ}\right)$
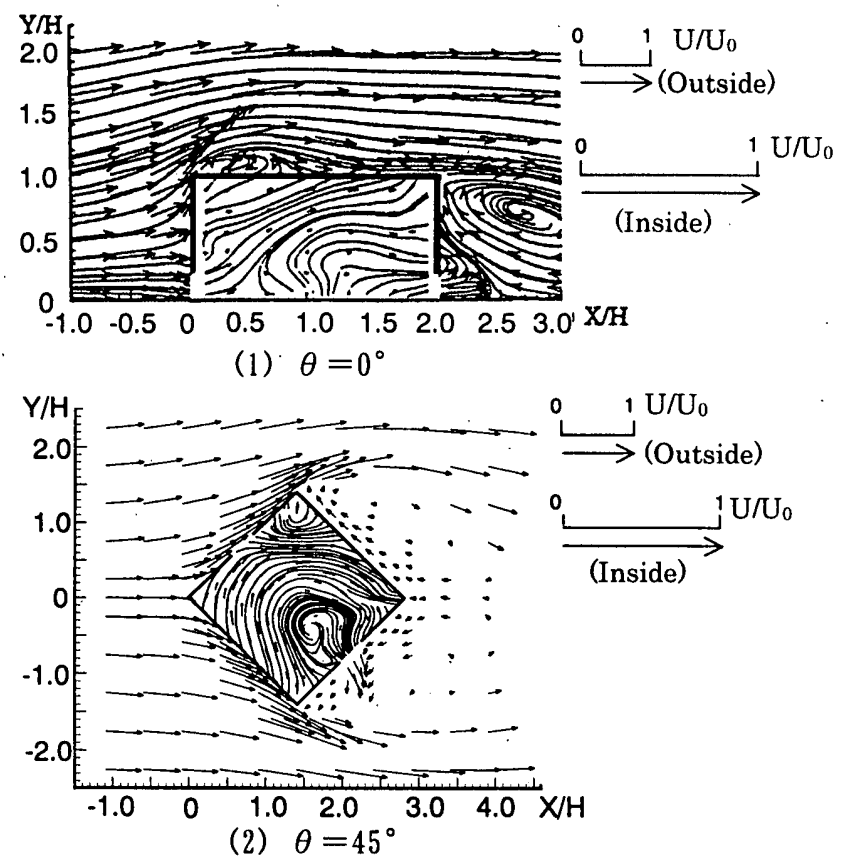

図 -8 通風模型周りの水平風速ベクトル分布

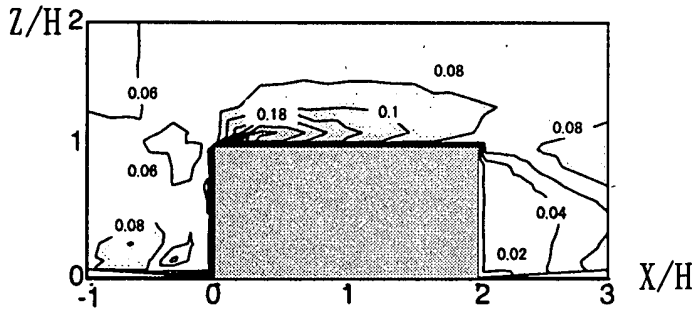

図－9＼cjkstart開口部なし模型周りの乱流エネルギー分布 
部で循環副を形成する気流の 3 つに分かれた。通風㫻道として、流 入気流は下降して床面に到達した後に上昇しながら、その一部が風 下開口部から流出した。流出した気流は模型後流の循環淐に誘引さ れて上方に流れた。室内に反時計回りの循睘流が形成された。模型 上流面下部の循環副は、 $\mathrm{X} / \mathrm{H}=-0.5 、 \mathrm{Z} / \mathrm{H}=0.3$ に珮中心が存在した。 この循臯瀜により圧力が負圧になって次第にアプローチフローが下 降し始め、さらに開口部の直上壁面を下降する気流の作用で流入気 流が下向きに押される結果、気流が斜めに開口部を下降して室内に 流入した。

図一 8 に水平断面の風向角 $\theta=0^{\circ}$ と $45^{\circ}$ の水平面風速ベクトル 分布を示す。測定高さは $\mathrm{Z} / \mathrm{H}=0.5$ で、 $\theta=0^{\circ}$ は風洞の流れに対して 右側域のみ測定した。模型外周部では風上側端部で流れが剥離し、 同じ側壁面で再付着した。開口部近傍の風速は簿流現鱼で加速され たが、流入気流が室内で下降するために測定した室中央域の風速は 減速した。そのため循環流は明暸でない。流出気流は模型後流域の 風速よりも加速され、後流の洞は $\mathrm{X} / \mathrm{H}=2.7 、 \mathrm{Y} / \mathrm{H}=0.65$ 付近に中心 が形成された。

風向角 $\theta=45^{\circ}$ の模型外周部では、流れが風上側端部で分岐し、 前面の壁に治って流れ、風上開口部から室内に流入する。流入開口 部直近の風速ベクトルが前面の壁面に治っている。従って、流入気 流は開口部直近の気流よりも、建物先端部で分岐した流れが建物前 面の壁面に沿って開口部に到達し流入したと判断される。室内へ流 入直後は、アプローチフローの風向と同じ風向分布が観測され、大 きな時計迴りの瀜を形成した。佩の中心は吸引勃果で流出開口部に 寄った位置に存在した。室内気流は流入開口部の流入角とほほ反対 の角度で流出開口部から流出した。

(2) 乱流エネルギー

図ー9に開口部なし建物模型の乱流エネルギー $\mathrm{k} / \mathrm{Uo}^{2}$ 結果を示 す。屋根面前緑部で剥離した気流の影篦で大きな乱れが屋根面端部 で形成された。図ー10 に通風模型の結果を示す。開口部なし模型と 同様に、建物前面下部と屋根面端部で高レベルの籍囲が広がったが、 屋根面の乱れは開口部なし模型に比べてやや低下した。室内では流 入開口部の風下側で 0.07 と比較的大きい值をとり、斜め下方に流入 する主流に治って拡散し、流出側壁面近傍で 0.01 の低い值を示した。 後流域では、流出気流と建物後流が相互作用する領域で 0.06 の高い 值を示した。

（3）平均風圧保数

図-11 に通風模型外部表面の平均風圧係数分布を示す。風上面 の最大風圧係数は 0.8 で、流入開口部近傍で $0.6 \sim 0.7$ に分布した。 風下面は -0.2 前後の負圧で、室内天井面は 0.2 の正圧を示した。 図-12 に開口部なし建物模型の平均風圧係数分布を示す。風上面 の最大風圧係数は 0.75 を示し、風下面はほぼ均一なー0.15〜 - 0.18 の風圧係数であった。

\section{2 流入気流の降下現象}

アプローチフローが建物開口部に正対する条件では、開口部が建 物前面中央に存在する場合、流入気流が室内で急激に下降すること が知られている 17)。そこで、開口部高さで通風模型内外の気流性状 を検討した。

（1）迎角分布

図一 13 に迎角分布を示す。流入開口部前方に形成される循環温の

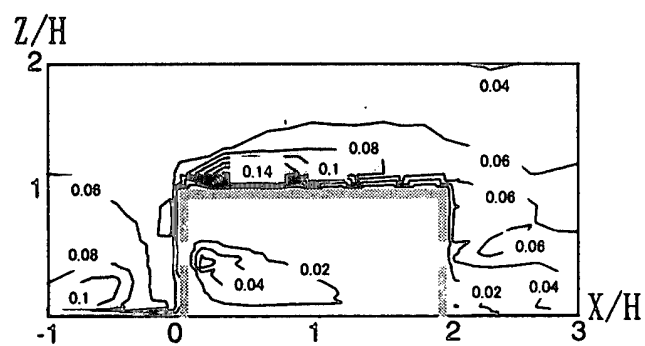

図-10 通風模型周りの乱流エネルギー分布



(1)風上面



（2）風下面
図-11 通風模型の平均風圧係数分布



（1)風上面

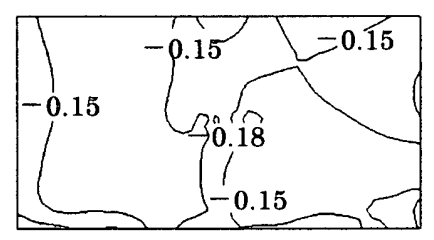

(2)風下面
図-12 開口部なし模型の平均風圧係数分布

迎角 $\delta\left[{ }^{\circ}\right]$

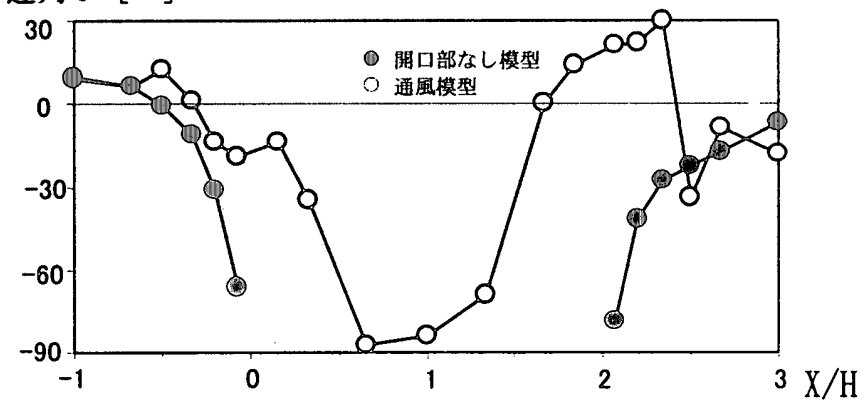

図-13 開口部中心高さでの迎角分布

U/Uo, W/Uo

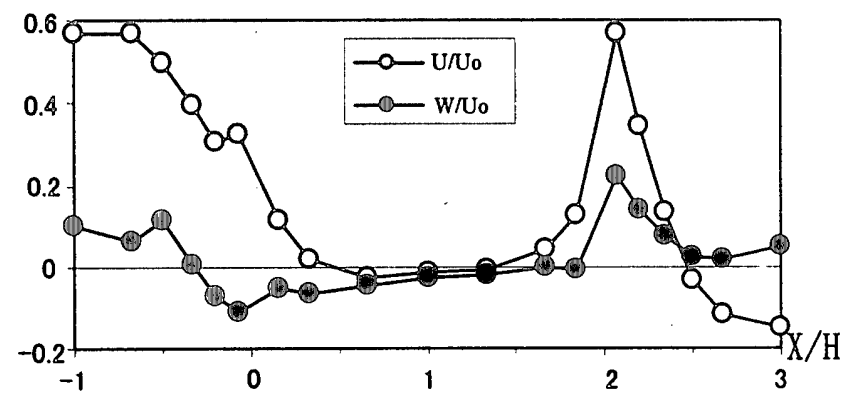

図-14 開口部中心高さでの主流方向と銛直方向の速度分布 
影響で、開口部近くで下向きの鈶直速度成分が増加し、さらに開口 部直上の風上壁面を下降する気流の作用で流入気流が下向きに押さ れる結果、開口部に近づくと迎角は正から負に㚆化した。開口部流 入直前の流入角は $19^{\circ}$ の下向き角度を示した。室内に流入した気流 は休面に向かって下降し、その後、流出開口部に対して上向き角度 で流出した後、模型後流域の湆流に誘引されて上昇した。

（2）運動量分布とシヤーストレス分布

図-14 に主流方向速度 U と鈆直方向速度 W の分布を、図-15 に運動量分布とシヤーストレス分布を示す。流入開口部に近づくに 従い、建物前面下部の循環域により圧力勾配が変化し、主流方向速 度を減じながら鈶直方向速度が正から負に変化する。それに伴い、 鈶直方向の運動量輸送 UW が正から負に変化し、さらに開口部直上 の下降気流の作用が加わり、流入開口部直前で流入気流に下向きの 力を及ぼす運動量が形成された。シヤーストレスは負から正に変化 したが、変化量は運動量に比べて小さかった。従って、流入気流の 下降現象は開口部直前における下向きの運動量輸送の增加が要因で あると考えられる畔 4 ，5)。開口部前後の短い区間で減速、加速、減 速が生じる複雑な流れが形成されていた。

\section{3 流入開口部近管と室内の風速变動スベクトル分布}

図ー16 に通風時の流入開口部前後と室内のスペクトル分布を示 す。流入後の $\mathrm{X} / \mathrm{H}=1 / 6$ では流入直前の $\mathrm{X} / \mathrm{H}=-1 / 6$ に比べて、 $\mathrm{Y}$ 成 分と $\mathrm{Z}$ 成分のピークが高周波側に形成され、とくに Z 成分は大幅に ピーク時の無次元周波数がシフトした。アプローチフローが室内に 流入した時、開口部と室内の乱れがアプローチフローの Y 成分と $\mathrm{Z}$ 成分に付加されたと考えられる。主流方向のスペクトルは図一 2 の スペクトル分布に似ており、アプローチフローの乱れ X 成分が室内 で持続された。 $\mathrm{X} / \mathrm{H}=1 / 3$ と $\mathrm{X} / \mathrm{H}=2 / 3$ でも $\mathrm{Y}$ 成分と $\mathrm{Z}$ 成分のピーク がX成分に比べて高周波数側に存在した。

\section{4 開口部の流入気流と通風}

(1) 開口部流入気流の流入角と流入風速

図-17に風上開口部前緑の流入角と接近流の風向角との関係を 示す。水平面の流入角 $\beta$ はスプリット風速計の $\mathrm{X}$ 成分と $\mathrm{Y}$ 成分から 算出した。測定点は開口部前縁の 3 点で、測定高さは $\mathrm{Z} / \mathrm{H}=0.5$ であ る。アプローチフローが模型に正対する場合、流れの縮流現象によ り $\mathrm{A}$ 点と $\mathrm{C}$ 点の流入角が対称であった。風向角 $45^{\circ}$ までは、流入 気流は壁面に治う接線方向速度の影響で風向角よりも大きな角度で 流入した。 $45^{\circ}$ 以上になると流入気流が壁厚に遮られる影憵で、 $45^{\circ} \leqq \theta \leqq 60^{\circ}$ で流入角は一定の傾向を示した。風向角が $60^{\circ}$ を 超えると、流入角は减少した。

図ー18に風向角と流入風速比の関倸を示す。アプローチフローが 模型に正对する場合、軒高風速の約 $50 \%$ の風速で上流側開口部から 室内に流入した。流入開口部の有効開口面積は風向角とともに隇少 して、風向角 $60^{\circ}$ まで流入風速が加速された。 $60^{\circ}$ を超えると、流 入風速比は減少した。

\section{（2）通風量}

図－19に風向角と通風量の関係を示す。風向角の増加に従い、流 入の有效開口面積が単調减少するので、風向角 $45^{\circ}$ まで通風量が緩 やかに減少した。風向角 $45^{\circ}$ から $50^{\circ}$ までの範囲で通風量が増加

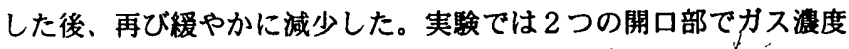
を測り、 $75^{\circ}$ まで上流側開口部からカスが同時に流出していないこ



図ー15 開口部中心高さでの運動量分布とシヤーストレス分布

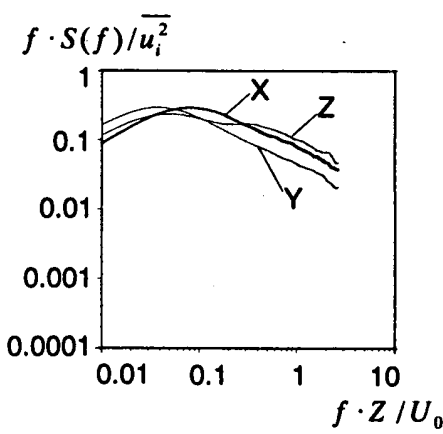

(1) 開口部直前 $\mathrm{X} / \mathrm{H}=-1 / 6$ $f \cdot S(f) / \overline{u_{i}^{2}}$

（3） 室内 $\mathrm{X} / \mathrm{H}=1 / 3$

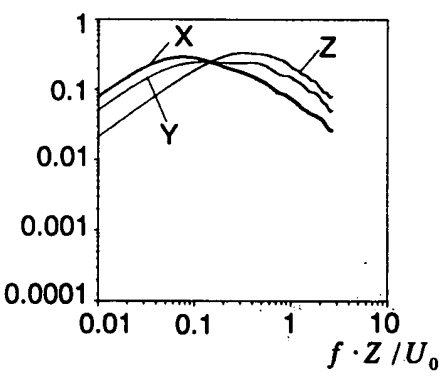

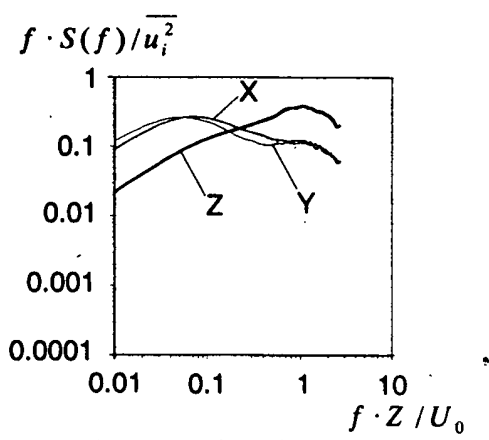

(2) 開口部直後 $\mathrm{X} / \mathrm{H}=1 / 6$

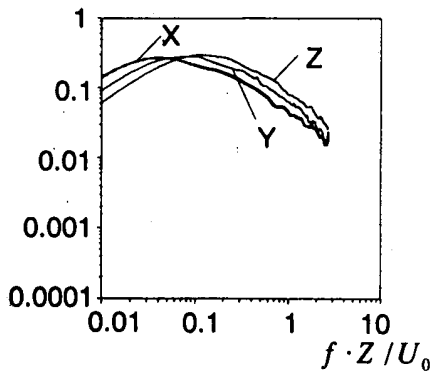

（4）室内 $\mathrm{X} / \mathrm{H}=2 / 3$ $f \cdot S(f) / \overline{u_{i}^{2}}$

図-16 開口部前後と室内の風速変動スペクトル分布
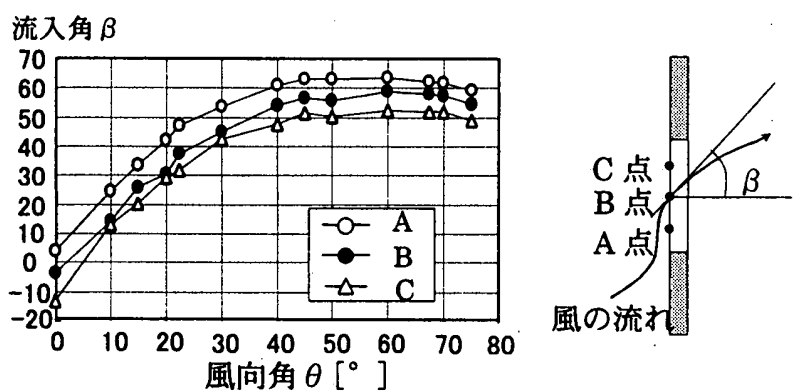

図-17 風向角と開口部流入角の関係

流入風速比 $\mathrm{Vp} / \mathrm{U}_{0}$

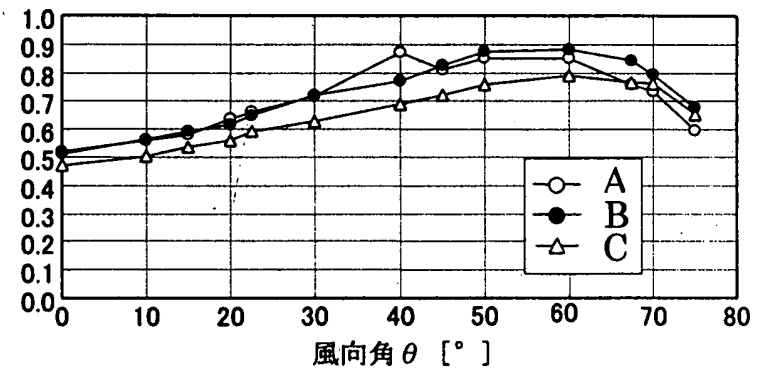

図-18 風向角之流入風速比の関係 
とを確認した。通風毁の增減現象の原因について、今後、開口部近 傍の流れと乱れの性状から詳細に検討する必要がある。

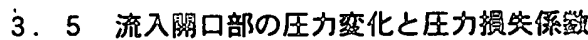

(1) 開口部の圧力変化

図ー20に開口部中心に位置する B 点の全圧、動圧、静圧及び室 内静圧を示す。開口部動圧はスプリット風速計の流入風速から計算 し、開口部静圧はピトー全圧管の全圧から開口部動圧を差し引いて 算出した。圧力は軒高風速の動圧で基準化した。天井面の室内静圧 分布は変動係数が風向角 $0^{\circ}$ で $4.5 \%$ 、風向角 $75^{\circ}$ でー5.6\%であっ た。開口部全圧は剥離流の影響が小さければ、ベルヌーイの定理に より風向角に対してほぼ一定の值が保持されるはずだが鲆4)、開口 部全圧は風向角 $40^{\circ}$ まで䋸やかに增大した。原因はピト一全圧管を 水平方向の流入角のみに合わせ、下降気流による迎角成分を考慮せ ずに全圧を測定したことに起因しており、とくに下降気流の迎角が 大きい風向角 $0^{\circ} \sim 22.5^{\circ}$ の範囲で、全圧が過小脬価された可能性 が強い。開口部全圧は $40^{\circ}$ を超えた辺りから下降傾向がみられた。 模型風上端部で発生する剥離流により乱れが生産される結果、全圧 が低下したと考えられる㽣6!。模型上流のエネルギーが室内で消失 し、最終的なエネルギーの到達レベルが室内静圧に転化すると仮定 し、室内静圧基準で開口部損失を表現すれば、全圧損失は $0^{\circ}<\theta$ $\leqq 40^{\circ}$ まで增大し、 $40^{\circ}<\theta<60^{\circ}$ で一定になり、 $\theta>60^{\circ}$ で全圧 が急激に減少するために全圧損失が減少した。開口部の静圧損失は 風向角によらずほぼ一定值を示した。動圧損失は流入風速の加速が 続く $60^{\circ}$ まで増大した。

(2) 開口部の圧力損失倸数

圧力損失係效 とを開口部流入風速 $V_{P}$ の通過動圧、及び開口部全 圧 $\mathrm{P}_{\mathrm{T}}$ と室内静压 $\mathrm{P}_{\mathrm{R}}$ の圧力差で定羲する。

$$
\zeta=\left(\mathrm{P}_{\mathrm{T}}-\mathrm{P}_{\mathrm{R}}\right) /\left[\rho\left(\mathrm{V}_{\mathrm{P}}\right)^{2 / 2}\right]
$$

対比に従来の開口部なし模型の壁面風圧を用いた圧力損失係效 18 )

$$
\zeta^{\prime}=\left(\mathrm{P}_{W}-\mathrm{P}_{\mathrm{R}}\right) /\left[\rho(\mathrm{Q} / \mathrm{A})^{2} / 2\right]
$$

を計算した。図ー21に風向角と圧力損失倸效の関係を示す。従来型

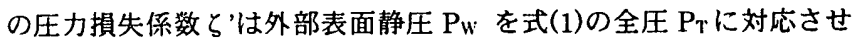

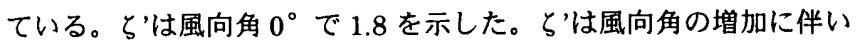
増加し、風向角 $30^{\circ} \sim 90^{\circ}$ で最大值を示すとの報告がある4!。本測 定では通風量が単調減少から風向角 $45^{\circ} \sim 50^{\circ}$ で増加に転じ、その 後、再び緩やかに減少した。その結果、ら'は風向角 $45^{\circ}$ から $50^{\circ}$ で減少した後、 $60^{\circ}$ から $70^{\circ}$ で增加傾向がみられた。開口部全圧を 用いた圧力提失係数 $\zeta は$ 風向角 $0^{\circ} \sim 22.5^{\circ}$ の筑囲で全圧の過小諘

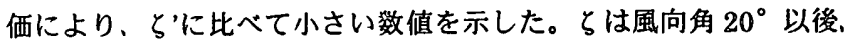
緩やかに減衰した。式(1)の開口部風速はポイント風速を、式(2)の 風速はバルク風速を示す。風向角が大きくなる場合は、流入角が $45^{\circ}$ まで風向角に比例するので、 $\mathrm{V}_{\mathrm{P}}$ と Q/A の風速差が拡大して とら’の差異は增大すると考えられる。

図-22 に流入角と圧力損失係数 $\zeta$ の関係を示す。流入角が $0^{\circ} \sim$ $30^{\circ}$ でらが 1.5 付近の一定を示し、それ以降は流入角の増大に伴い 低下する傾向がみられた。圧力損失係数が流入角と風向角に依存す ることが判る。今後、珐力損失係数と流入角を一意的に表す方法に ついて検討を進める必要がある。

4. 结語

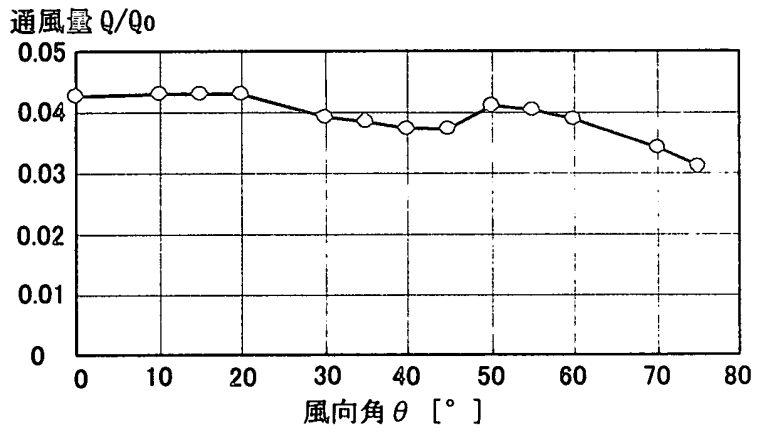

図-19 風向角之通風量の関係

圧力 $\mathrm{P} / \mathrm{P} 0$

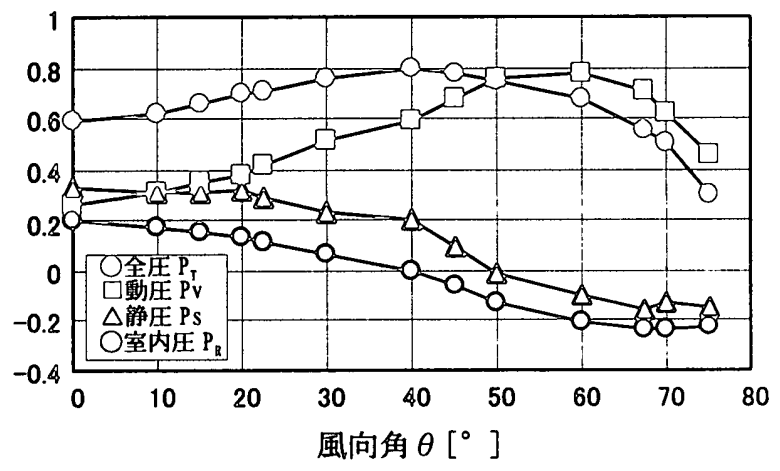

図 - 20 風向角と開口部圧力の関係

圧力損失係数 $\zeta, \zeta ，$

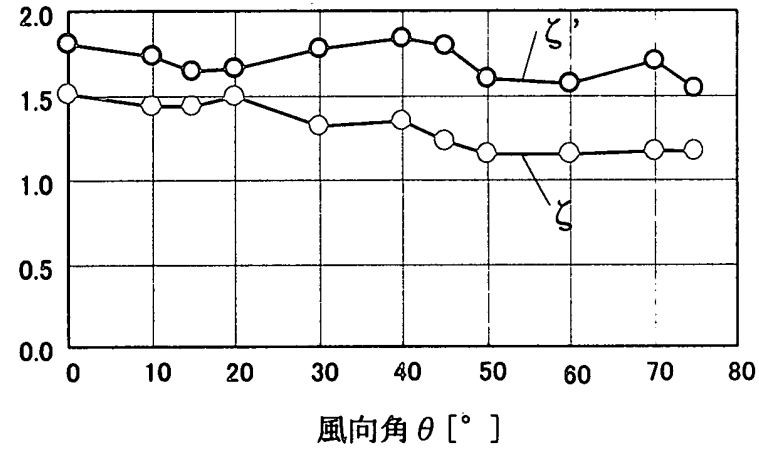

図-21 風向角と圧力損失係数の関係

圧力損失係数

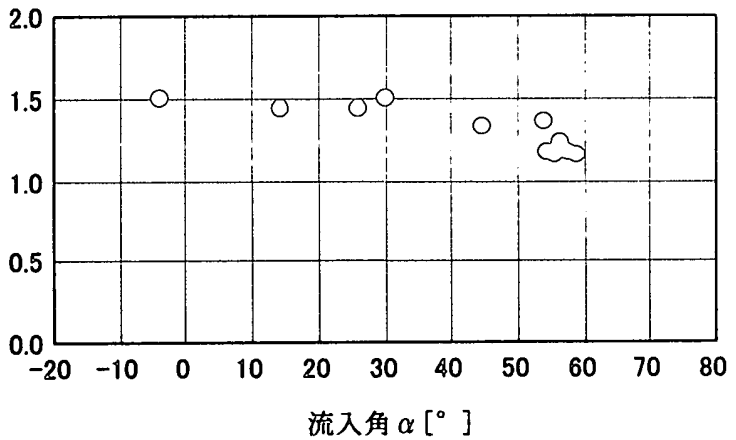

図-22 流入角之圧力損失係数の関係 
本実験条件で通風開口部の流入気流と圧力損失に関して、次の結 果を得た。

（1）アプローチフローが建物開ロ部に正対する条件では、建物前 面下部に形成される循環流と開口部直上面を下降する気流との相互 作用により、下向きの運動量輸送が開口部直前で増大し、流入気流 が開口部を急激に下降しながら室内に流入した。

（2）開口部全圧は、風向角が $40^{\circ}$ を超えた辺りから、模型風上端 部で発生する剥離流による乱れ生産の影響により低下した。

（3）通風室内の主流方向のスペクトル成分はアプローチフローの 影響を強く受けた。

（4）開口部の流入気流は、風向角 $45^{\circ}$ まで風向角よりも大きな 流入角度で流入し， $45^{\circ} \leqq \theta \leqq 60^{\circ}$ で流入角は一定の傾向を示し た。

（5）開口部の全圧損失は風向角 $40^{\circ}$ まで増大し、 $40^{\circ}<\theta<60^{\circ}$ で一定になり、 $\theta>60^{\circ}$ で減少した。開口部の静圧損失は風向角に よらずほほ一定值を示した。

（6）開口部の圧力損失係数は流入角と風向角に依存した。

謝辞 本実験を行うに当り、東京工芸大学と東京理科大学の卒研生 及び元東京理科大学院生岩㴊拓志氏の協力を得た。ここに樑謝する。

〈主な記号〉

$A$ : 開口部面積、 $A=0.0018\left[\mathrm{~m}^{2}\right]$

$\mathrm{C}_{\mathrm{w}}$ : 平均風圧係数、 $\mathrm{C}_{\mathrm{w}}=\mathrm{Pw}_{\mathrm{w}} / \mathrm{Po}_{0}$

$\mathrm{H}$ : 模型高さ、 $\mathrm{H}=0.15[\mathrm{~m}]$

$\mathrm{f}$ : 周波数 $[1 / \mathrm{s}]$

$\mathrm{k}:$ 乱流エネルギー, $\mathrm{k}=\overline{\left(\mathrm{u}^{2}+\mathrm{v}^{2}+\mathrm{w}^{2}\right)} / 2 \quad\left[\mathrm{~m}^{2} / \mathrm{s}^{2}\right]$

$\mathrm{P}_{0}$ : 基準動圧で、軒高風速の動圧 $[\mathrm{Pa}]$

$\mathrm{P}_{\mathrm{T}}$ : 開口部全圧 $[\mathrm{Pa}]$

$\mathrm{P}_{\mathrm{V}}:$ 開口部動圧 $[\mathrm{Pa}]$

$\mathrm{PS}_{\mathrm{S}}$ : 開口部静压 $[\mathrm{Pa}$

$\mathrm{P}_{\mathrm{R}}:$ 室内静圧 $[\mathrm{Pa}]$

$\mathrm{P}_{W}$ : 壁面風圧 $[\mathrm{Pa}]$

$Q$ : 通風量 $\left[\mathrm{m}^{3} / \mathrm{s}\right]$

$\mathrm{Q}_{0}$ : 基準風量 $\mathrm{Q}_{0}=\mathrm{H}^{2} \cdot \mathrm{U}_{0}$

$\mathrm{S}(\mathrm{f}):$ パワースペクトル $\left[\mathrm{m}^{2} / \mathrm{s}\right]$

$\mathrm{U}_{0}$ : 軒高風速 $[\mathrm{m} / \mathrm{s}]$.

$\mathrm{U}, \mathrm{V}, \mathrm{W}$ : 風速の 3 成分 $[\mathrm{m} / \mathrm{s}]$

$\mathrm{u}, \mathrm{v}, \mathrm{w}$ : 乱れの 3 成分 $[\mathrm{m} / \mathrm{s}]$

$V_{\mathrm{P}}$ : 開口部流入風速、 $\quad V p=\sqrt{U^{2}+V^{2}}[\mathrm{~m} / \mathrm{s}]$

$\beta:$ 流入角 $\left.{ }^{\circ}{ }^{\circ}\right]$

$\delta:$ 迎角 $\left[{ }^{\circ}\right]$

$\theta:$ 風向角 $\left[{ }^{\circ}\right]$

$\rho:$ 空気密度 $\left[\mathrm{kg} / \mathrm{m}^{3}\right]$

$\zeta 、 \zeta^{\prime}:$ 压力損失係数

\section{参考文献}

1) 村上周三、小林信行、加藤信介、赤林伸一、住宅の自然通風に関する実験 的研究、日本建築学会計画系論文報告集、372、10-19, 1987.2

2）義江龍一郎、オフィスビルにおける自然換気併用空調方式の省エネルギー

効果、日本建築学会大会学術講演梗概集、535-536, 2000.9

3) 石原正雄、建策換気設計、213,261-262, 朝倉書店、1969

4) 清田誠良、関根媇、模型壁面の開口部圧力損失に関する实㷂的研究、日本 建築学会啨境工学論文集、6、77-83、1984.11

5) 甲谷韦史、山中俊夫、古川準、直列配固された複数開口を持つ建物にお ける通風量算定法に関する基碳研究 その $2 \sim$ そ 3 、日本建築学会大会学 術講演梗概集、5 51 - $554 、 2000.9$

6) 加藤信介、パワーバランスモデルに基づく通風量算出モデル、日本建策学 会㙞境工学委員会第 1 回空気シンボジウム 通風量萛出のモデリンク、45-48, 1990.11

7) 澤地孝男、瀬戸裕直、清田誠良、成田健一，安部仵美、住宅の通風設計お よび評価性能に関する研究 その 5 、'日本建築学会大会学術講演梗概集、
$571.572,2000.9$

8) 西田勝、片山忠久、石井昭夫、堤純一郎、石井米二郎、風洞模型実殹によ る通風の駆動力と室内気流分布の再現性に関する研究、日本建篹学会計画系 諭文報告集、375, 1-8, 1987.5

9) 何平、片山忠久、単室モテルの通風量に関する数值シミュレーションによ る基磁的検討、日本建策学会計面系馀文報告集、474、47-55, 1995.8

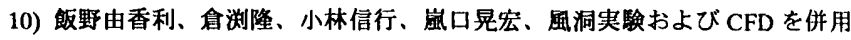
した通風時の開口条件や主風向が異なる場合における建物内外の気流性状に 関する研究、日本建学会計画系論文報告集、520、47-54, 1999.6

11）清田誠良、関根毅、建策物周囲空間の静圧分布に関する実験的研究、日 本建築学会計画系諭文報告集、397、23-29, 1989.3

12）村上周三、CFDによる建簿・都市の聚境設計工学、東京大学出版会、2000 13）鈴木求紀、倉㴊隆、大場正昭、嵐口晃宏、岩㴊拓志、小橋史彦、通風時 の建物内外気流構造解明のための数值シミュレーショシに関する研究 (3)

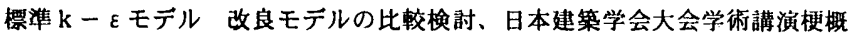
集、701-702, 2000.9

14）金永徳、村上周三、赤林伸一、通風量算出モテルに関する基整的研究 そ の 2、49-52、日本建築学会関東支部学術講演梗概集、1991.3

15）日本建築センター編、実務者のための建筑物風洞実験ガイドブック、32-35, 1994

16）村上周三、赤林伸一、トレーサーカスス法を利用した住宅の自然通風に関 する風洞実験、日本風工学誌、33, $1-8,1987.9$

17）金水徳、村上周三、赤林伸一、住宅における通風時の室内外の流扎場の 可視化、日本建築学会環境工学委員会第 1 回空気シンボジウム 通風量算出 のモデリング、17-20, 1990.11

18）清田誠良、関根毅、模型壁面の開口部圧力損失に関する実験的研究（綍 報)、日本建箱学会計画系馀文報告集、398、47-54, 1989.4

\section{本論文に関する既発表碖文}

1) 入江潇治、大場正昭、倉㴊隆、通風時の室内気流空間分布の予測・評価手 法に関する研究 その 3 風洞実䍄による室内外の風速ベクトル分布に関す る検讨、日本建築学会大会学術講演梗概集、531-532, 1999.9

2）入江群治、大場正昭、倉㴊隆、通風時の室内気流空間分布の予測・評価手 法に関する研究 その 4 風洞実験による通風量及び室内風速変動スペクト ルに関する㮆封、日本建策学会大会学術講演梗概集、637-638，2000.9

3) M. Ohba, K. Irie, T. Kurabuchi, Study on airflow characteristics inside and outside a building induced by cross-ventilation using wind tunnel experiments, 317-320, $4^{\text {th }}$ Bluff Body Aerodynamics \& Applications, 2000.9

4) T. Kurabuchi, M. Ohba, A. Arashiguchi, T. Iwabuchi, Numerical study of airflow structure of a cross-ventilated model building, Roomvent 2000, 1, 313-318, 2000.7 5) 岩㴊拓志、倉㴊隆、栭口晃宏、大場正昭、通風時建物内外気流の構造解明 を目的とした LES シミュレーション、空気調和・衛生工学会講演諭文集、 1185-1188, 2000.9

6) 倉㴊隆、大場正昭、䛜口晃宏、岩㴊拓志、小橋史彦、通風時の建物内外気 流構造解明のための数值シミュレーションに関する研究(5) 計算結果の分析 に基づく通風時の乱流棈造の解明、日本建築学会大会学術講演梗概集、 705-706, 2000.9

（2001年 5 月 7 日原稿受理，2001年 9 月 27 日採用決定） 